Research article

\title{
Peroxisome proliferator-activated receptor $\gamma 1$ expression is diminished in human osteoarthritic cartilage and is downregulated by interleukin-1 $\beta$ in articular chondrocytes
}

\author{
Hassan Afif1, Mohamed Benderdour², Leandra Mfuna-Endam¹, Johanne Martel-Pelletier1, Jean- \\ Pierre Pelletier ${ }^{1}$, Nicholas Duval ${ }^{3}$ and Hassan Fahmi ${ }^{1}$
}

\begin{abstract}
1Osteoarthritis Research Unit, Centre Hospitalier de l'Université de Montréal (CHUM), Notre-Dame Hospital, Department of Medicine, University of Montreal, Montreal, 1560 Sherbrooke East, Pavillon J.A DeSève, Y-2628, Montreal, QC, H2L 4M1, Canada

${ }^{2}$ Centre de Recherche, Sacré-Coeur Hospital, 5400 Boulevard Gouin Ouest, Montréal, QC, H4J 1C5, Canada

${ }^{3}$ Centre de Convalescence, Pavillon de Charmilles, 1487 Boulevard des Laurentides, Montréal, OC, H7M 2Y3, Canada
\end{abstract}

Corresponding author: Hassan Fahmi, h.fahmi@umontreal.ca

Received: 30 Oct 2006 Revisions requested: 11 Jan 2007 Revisions received: 26 Feb 2007 Accepted: 26 Mar 2007 Published: 26 Mar 2007

Arthritis Research \& Therapy 2007, 9:R31 (doi:10.1186/ar2151)

This article is online at: http://arthritis-research.com/content/9/2/R31

(c) 2007 Afif et al.; licensee BioMed Central Ltd.

This is an open access article distributed under the terms of the Creative Commons Attribution License (http://creativecommons.org/licenses/by/2.0), which permits unrestricted use, distribution, and reproduction in any medium, provided the original work is properly cited.

\begin{abstract}
Peroxisome proliferator-activated receptor $\gamma(\operatorname{PPAR} \gamma)$ is a nuclear receptor involved in the regulation of many cellular processes. We and others have previously shown that PPAR $\gamma$ activators display anti-inflammatory and chondroprotective properties in vitro and improve the clinical course and histopathological features in an experimental animal model of osteoarthritis (OA). However, the expression and regulation of PPAR $\gamma$ expression in cartilage are poorly defined. This study was undertaken to investigate the quantitative expression and distribution of PPAR $\gamma$ in normal and OA cartilage and to evaluate the effect of IL-1 $\beta$, a prominent cytokine in OA, on PPAR $\gamma$ expression in cultured chondrocytes. Immunohistochemical analysis revealed that the levels of PPAR $\gamma$ protein expression were significantly lower in OA cartilage than in normal cartilage. Using real-time RT-PCR, we demonstrated that PPAR $\gamma 1$ mRNA levels were about 10-fold higher than PPAR $\gamma 2$ mRNA levels, and that only PPAR $\gamma 1$ was differentially expressed: its levels in OA cartilage was 2.4-fold lower than in normal cartilage $(p<$ $0.001)$. IL-1 treatment of OA chondrocytes downregulated PPAR $\gamma 1$ expression in a dose- and time-dependent manner. This
\end{abstract}

effect probably occurred at the transcriptional level, because IL1 decreases both PPAR 1 mRNA expression and PPAR 1 promoter activity. TNF- $\alpha, \mathrm{IL}-17$, and prostaglandin $\mathrm{E}_{2}\left(\mathrm{PGE}_{2}\right)$, which are involved in the pathogenesis of $O A$, also downregulated PPAR $\gamma 1$ expression. Specific inhibitors of the mitogen-activated protein kinases (MAPKs) p38 (SB203580) and c-Jun N-terminal kinase (SP600125), but not of extracellular signal-regulated kinase (PD98059), prevented IL-1-induced downregulation of PPAR $\gamma 1$ expression. Similarly, inhibitors of NF- $\kappa B$ signaling (pyrrolidine dithiocarbamate, MG-132, and SN50) abolished the suppressive effect of IL-1. Thus, our study demonstrated that PPAR $\gamma 1$ is downregulated in OA cartilage. The pro-inflammatory cytokine IL-1 may be responsible for this downregulation via a mechanism involving activation of the MAPKs (p38 and JNK) and NF- $\mathrm{KB}$ signaling pathways. The IL-1induced downregulation of PPAR $\gamma$ expression might be a new and additional important process by which IL-1 promotes articular inflammation and cartilage degradation.

\section{Introduction}

Osteoarthritis (OA) is the most common joint disorder, accounting for a large proportion of disability in adults. It is characterized by the progressive destruction of articular carti- lage, and excessive production of several pro-inflammatory mediators [1-3]. Among these mediators, IL-1 $\beta$ has been shown to be predominantly involved in the initiation and progression of the disease [1-3]. Exposure of chondrocytes to IL-

$\overline{\mathrm{AP}-1}=$ activator protein 1; COX = cyclooxygenase; DMEM = Dulbecco's modified Eagle's medium; ERK - extracellular signal-regulated kinase; FCS = fetal calf serum; GAPDH = glyceraldehyde-3-phosphate dehydrogenase; IL= interleukin; JNK= c-Jun N-terminal kinase; MAPK = mitogen-activated protein kinase; MMP = metalloproteinase; $\mathrm{mPGES}=$ membrane-associated prostaglandin $\mathrm{E}$ synthase; NF- $\kappa \mathrm{B}=$ nuclear factor- $\kappa \mathrm{B} ; \mathrm{OA}=\mathrm{osteoarthri-}$ tis; $\mathrm{PDTC}=$ pyrrolidine dithiocarbamate; $\mathrm{PG}=$ prostaglandin; $\mathrm{PGE}_{2}=$ prostaglandin $\mathrm{E}_{2} ; \mathrm{PPAR}=$ peroxisome proliferator-activated receptor; $\mathrm{RT}-\mathrm{PCR}$ $=$ reverse-transcriptase-mediated polymerase chain reaction; TNF $=$ tumor necrosis factor. 
1 induces a cascade of inflammatory and catabolic events including the upregulation of genes encoding matrix metalloproteinases (MMPs), aggrecanases, inducible nitric oxide synthase, cyclooxygenase-2 (COX-2), and microsomal prostaglandin E synthase-1 (mPGES-1) [1-4], leading to articular inflammation and destruction. Although the role of increased inflammatory and catabolic responses in OA is well documented, little is known about the endogenous signals and pathways that negatively regulate these events. Thus, identification and characterization of these pathways is of major importance in improving our understanding of the pathogenesis of OA and may be helpful in the development of new efficacious therapeutic strategies.

Peroxisome proliferator-activated receptors (PPARs) are a family of ligand-activated transcription factors belonging to the nuclear receptor superfamily [5]. So far, three PPAR subtypes have been identified: PPAR $\alpha, \operatorname{PPAR} \beta / \delta$, and PPAR $\gamma$. PPAR $\alpha$ is present mostly in the liver, heart, and muscle, where it is the target of the fibrate class of drugs and is believed to function in the catabolism of fatty acid [6]. PPAR $\beta / \delta$ is fairly ubiquitous and seems to be important in lipid and energy homeostasis [7]. PPAR $\gamma$ is the most studied form of PPAR. At least two PPAR $\gamma$ isoforms have been identified that are derived from the same gene by the use of alternative promoters and differential mRNA splicing $[8,9]$. PPAR $\gamma 1$ is found in a broad range of tissues, whereas PPAR $\gamma 2$ is expressed mainly in adipose tissue [10].

Several lines of evidence suggest that PPAR $\gamma$ activation may have therapeutic benefits in OA and possibly other chronic articular diseases. We and others have shown that PPAR $\gamma$ is expressed and functionally active in chondrocytes and that PPAR $\gamma$ activators modulate the expression of several genes considered essential in the pathogenesis of OA. PPAR $\gamma$ activation inhibits the IL-1-induced expression of inducible nitric oxide synthase, MMP-13, COX-2, and mPGES-1 in chondrocytes $[4,11,12]$. Moreover, pretreatment with PPAR $\gamma$ activators prevents IL-1-induced proteoglycan degradation [13]. Additionally, PPAR $\gamma$ activation in synovial fibroblasts prevents the expression of IL-1, TNF- $\alpha$, MMP-1, COX-2, and mPGES-1 [14-16]. The inhibitory effect of PPAR $\gamma$ is partly due to antagonizing the transcriptional activity of the transcription factors $\mathrm{NF}-\kappa \mathrm{B}$, activator protein 1 (AP-1), signal transducers and activators of transcription (STATs), and Egr-1 [16,17]. The protective effect of PPAR $\gamma$ activators has also been demonstrated in several animal models of arthritis, including a guinea-pig model of OA [18]. In that study, pioglitazone, a PPAR $\gamma$ activator, reduced cartilage degradation as well as $\mathrm{IL}-1$ and MMP-13 expression [18]. Together, these data indicate that PPAR $\gamma$ may constitute a new therapeutic target in treating $\mathrm{OA}$.

Although a considerable amount is known on the effects of PPAR $\gamma$ activation on inflammatory and catabolic responses in articular tissues, little is known about PPAR $\gamma$ expression and regulation in these tissues. To improve our understanding of the biology of PPAR $\gamma$ in OA, we compared the expression of PPAR $\gamma$ in normal and OA cartilage. In addition, we investigated the effect of IL-1 on PPAR $\gamma$ expression in human OA chondrocytes.

\section{Materials and methods Reagents}

Recombinant human IL-1 $\beta$ was obtained from Genzyme (Cambridge, MA, USA), and recombinant human TNF- $\alpha$ and recombinant human IL-17 were from R\&D Systems (Minneapolis, $\mathrm{MN}, \mathrm{USA})$. Prostaglandin $\mathrm{E}_{2}\left(\mathrm{PGE}_{2}\right)$ was from Cayman Chemical Co. (Ann Arbor, MI, USA). SB203580, SP600125, PD98059, pyrrolidine dithiocarbamate (PDTC), MG-132 and SN-50 were from Calbiochem (La Jolla, CA, USA). DMEM, penicillin and streptomycin, FCS, and $\mathrm{TRIzo}^{\circledR}$ reagent were from Invitrogen (Burlington, ON, Canada). All other chemicals were purchased from either Bio-Rad (Mississauga, ON, Canada) or Sigma-Aldrich Canada (Oakville, ON, Canada).

\section{Specimen selection and chondrocyte culture}

Human normal cartilage (from femoral chondyles) was obtained at necropsy, within 12 hours of death, from donors with no history of arthritic diseases $(n=18$, age $61 \pm 15$ years (mean $\pm \mathrm{SD})$ ). To ensure that only normal tissue was used, cartilage specimens were thoroughly examined both macroscopically and microscopically. Only those with neither alteration were processed further. Human OA cartilage was obtained from patients undergoing total knee replacement $(n$ $=41$, age $64 \pm 14$ years (mean $\pm \mathrm{SD}$ )). All patients with $\mathrm{OA}$ were diagnosed on criteria developed by the American College of Rheumatology Diagnostic Subcommittee for OA [19]. At the time of surgery, the patients had symptomatic disease requiring medical treatment in the form of non-steroidal antiinflammatory drugs or selective COX-2 inhibitors. Patients who had received intra-articular injections of steroids were excluded. The Clinical Research Ethics Committee of NotreDame Hospital approved the study protocol and the use of human tissues.

Chondrocytes were released from cartilage by sequential enzymatic digestion as described previously [11]. In brief, this consisted of $2 \mathrm{mg} / \mathrm{ml}$ pronase for 1 hour followed by $1 \mathrm{mg} / \mathrm{ml}$ collagenase for 6 hours (type IV; Sigma-Aldrich) at $37^{\circ} \mathrm{C}$ in DMEM and antibiotics $(100 \mathrm{U} / \mathrm{ml}$ penicillin, $100 \mu \mathrm{g} / \mathrm{ml}$ streptomycin). The digested tissue was briefly centrifuged and the pellet was washed. The isolated chondrocytes were seeded at high density in tissue culture flasks and cultured in DMEM supplemented with $10 \%$ heat-inactivated FCS. At confluence, the chondrocytes were detached, seeded at high density, and allowed to grow in DMEM supplemented as above. The culture medium was changed every second day, and 24 hours before the experiment the cells were incubated in fresh medium containing $0.5 \%$ FCS. Only first-passaged chondrocytes were used. 


\section{Immunohistochemistry}

Cartilage specimens were processed for immunohistochemistry as described previously [4]. The specimens were fixed in 4\% paraformaldehyde and embedded in paraffin. Sections (5 $\mu \mathrm{m}$ thick) of paraffin-embedded specimens were deparaffinized in toluene, then dehydrated in a graded ethanol series. The specimens were then preincubated with chondroitinase ABC $(0.25 \mathrm{U} / \mathrm{ml}$ in PBS, $\mathrm{pH} 8.0)$ for 60 minutes at $37^{\circ} \mathrm{C}$, followed by incubation with Triton X-100 (0.3\%) for 30 minutes at $25^{\circ} \mathrm{C}$. Slides were then washed in PBS followed by $2 \%$ hydrogen peroxide/methanol for 15 minutes. They were further incubated for 60 minutes with $2 \%$ normal serum (Vector Laboratories, Burlingame, CA, USA) and overlaid with primary antibody for 18 hours at $4^{\circ} \mathrm{C}$ in a humidified chamber. The antibody was a rabbit polyclonal anti-human PPAR (Santa Cruz Biotechnology, Santa Cruz, CA, USA), used at $10 \mu \mathrm{g} / \mathrm{ml}$. This antibody recognizes the epitope of the sequence mapping of amino acids 8 to 106 at the $\mathrm{N}$ terminus of PPAR $\gamma$. Each slide was washed three times in PBS, $\mathrm{pH} 7.4$, and stained with the use of the avidin-biotin complex method (Vectastain ABC kit; Vector Laboratories). The color was developed with 3,3'diaminobenzidine (DAB) (Vector Laboratories) containing hydrogen peroxide. The slides were counterstained with eosin. The specificity of staining was evaluated by using antibody that had been preadsorbed ( 1 hour at $37^{\circ} \mathrm{C}$ ) with a 20 -fold molar excess of the protein fragment corresponding to amino acids 6 to 105 of human PPAR (Santa Cruz), and by replacing the primary antibody with non-immune rabbit IgG (Chemicon, Temecula, CA, USA; used at the same concentration as the primary antibody). The evaluation of positive-staining chondrocytes was performed with our previously published method [4]. For each specimen, six microscopic fields were examined under $\times 40$ magnification. The total number of chondrocytes and the number of positive-staining chondrocytes were evaluated and results were expressed as the percentage of chondrocytes that stained positive (cell score).

\section{RNA extraction and reverse transcriptase-polymerase chain reaction}

Total RNA from homogenized cartilage or stimulated chondrocytes was isolated by using $\mathrm{TRI} \mathrm{I}^{\circledR}$ reagent (Invitrogen) in accordance with the manufacturer's instructions. To remove contaminating DNA, isolated RNA was treated with RNasefree DNase I (Ambion, Austin, TX, USA). The RNA was quantified with the RiboGreen RNA quantitation kit (Molecular Probes, Eugene, OR, USA), dissolved in diethylpyrocarbonate-treated water and stored at $-80^{\circ} \mathrm{C}$ until use. Total RNA $(1 \mu \mathrm{g})$ was reverse-transcribed with Moloney murine leukemia virus reverse transcriptase (Fermentas, Burlington, ON, Canada) as detailed in the manufacturer's guidelines. One-fiftieth of the reverse transcriptase reaction was analyzed by real-time quantitative PCR as described below. The following primers were used: PPAR 1 sense, 5'-AAAGAAGCCAACACTAAACC-3'; PPAR $\gamma 2$ sense, 5'-GCGATTCCTTCACTGATAC-3'; common PPAR $\gamma 1$ and PPAR 2 antisense, 5'-CTTCCATTACGGAGAGATCC-3'; glyceraldehyde-3-phosphate dehydrogenase (GAPDH) sense, 5'CAGAACATCATCCCTGCCTCT-3'; and GAPDH antisense, 5'-GCTTGACAAAGTGGTCGTTGAG-3'.

\section{Real-time quantitative PCR}

Quantitative PCR analysis was performed in a total volume of $50 \mu$ containing template DNA, $200 \mathrm{nM}$ sense and antisense primers, $25 \mu$ of SYBR ${ }^{\circledR}$ Green master mix (Qiagen, Mississauga, ON, Canada) and uracil- $N$-glycosylase (UNG, $0.5 \mathrm{U}$; Epicentre Technologies, Madison, WI, USA). After incubation at $50^{\circ} \mathrm{C}$ for 2 minutes (UNG reaction), and at $95^{\circ} \mathrm{C}$ for $10 \mathrm{~min}$ utes (UNG inactivation and activation of the AmpliTaq Gold enzyme), the mixtures were subjected to 40 amplification cycles $\left(15 \mathrm{~s}\right.$ at $95^{\circ} \mathrm{C}$ for denaturation, and 1 minute for annealing and extension at $60^{\circ} \mathrm{C}$ ). Incorporation of SYBR Green dye into PCR products was monitored in real time with a GeneAmp 5700 Sequence detection system (Applied Biosystems, Foster City, CA, USA) allowing determination of the threshold cycle $\left(C_{t}\right)$ at which exponential amplification of PCR products begins. After PCR, dissociation curves were generated with one peak, indicating the specificity of the amplification. A threshold cycle $\left(C_{t}\right.$ value) was obtained from each amplification curve with the software provided by the manufacturer (Applied Biosystems).

Relative amounts of mRNA in normal and OA cartilage were determined with the use of the standard curve method. Serial dilutions of internal standards (plasmids containing cDNA of target genes) were included in each PCR run, and standard curves for the target gene and for GAPDH were generated by linear regression with a plot of $\log \left(C_{t}\right)$ against $\log (\mathrm{cDNA}$ relative dilution). $C_{t}$ values were then converted to the number of molecules. Relative mRNA expression in cultured chondrocytes was determined with the $\Delta \Delta C_{t}$ method, as detailed in the manufacturer's guidelines (Applied Biosystems). $A \Delta C_{t}$ value was first calculated by subtracting the $C_{t}$ value for the housekeeping gene GAPDH from the $C_{t}$ value for each sample. $A$ $\Delta \Delta C_{t}$ value was then calculated by subtracting the $\Delta C_{t}$ value of the control (unstimulated cells) from the $\Delta C_{t}$ value of each treatment. Fold changes compared with the control were then determined by raising 2 to the $-\Delta \Delta C_{t}$ power. Each PCR reaction generated only the expected specific amplicon as shown by the melting-temperature profiles of the final product and by gel electrophoresis of test PCR reactions. Each PCR was performed in triplicate on two separate occasions for each independent experiment.

\section{Plasmids and transient transfection}

The luciferase reporter construct pGL3-PPAR $\gamma 1 \mathrm{p} 3000$, containing a 3,000-base-pair fragment of the human PPAR 1 gene promoter, was kindly provided by Dr Johan Auwerx (Institut de Génétique et de Biologie Moléculaire et Cellulaire, Illkirch, France) [9]. $\beta$-Galactosidase reporter vector under the control of SV40 promoter (pSV40- $\beta$-galactosidase) was from 
Promega (Madison, WI, USA). Transient transfection experiments were performed with FuGene- 6 ( $1 \mu \mathrm{g}$ of DNA to $4 \mu \mathrm{l}$ of FuGene 6; Roche Applied Science, Laval, OC, Canada) in accordance with the manufacturer's recommended protocol. In brief, chondrocytes were seeded and grown to 50 to $60 \%$ confluence. The cells were transfected with $1 \mu \mathrm{g}$ of the reporter construct and $0.5 \mu \mathrm{g}$ of the internal control pSV40- $\beta$ galactosidase. Six hours later, the medium was replaced with DMEM containing $1 \%$ FCS. The next day, the cells were treated for 18 hours with or without IL-1. After harvesting, luciferase activity was determined and normalized to $\beta$-galactosidase activity [16].

\section{Western blot analysis}

Chondrocytes were lysed in ice-cold lysis buffer $(50 \mathrm{mM}$ Tris$\mathrm{HCl}, \mathrm{pH} 7.4,150 \mathrm{mM} \mathrm{NaCl}, 2 \mathrm{mM}$ EDTA, 1 mM PMSF, $10 \mu \mathrm{g} /$ $\mathrm{ml}$ each of aprotinin, leupeptin, and pepstatin, $1 \%$ Nonidet $\mathrm{P} 40,1 \mathrm{mM} \mathrm{Na}_{3} \mathrm{VO}_{4}, 1 \mathrm{mM} \mathrm{NaF}$ ). Lysates were sonicated on ice and centrifuged at 12,000 r.p.m. for 15 minutes. The protein concentration of the supernatant was determined with the bicinchoninic acid method (Pierce, Rockford, IL, USA). Total cell lysate $(20 \mu \mathrm{g})$ was subjected to SDS-PAGE and electrotransferred to a nitrocellulose membrane (Bio-Rad). After blocking in $20 \mathrm{mM}$ Tris- $\mathrm{HCl}, \mathrm{pH} 7.5$, containing $150 \mathrm{mM} \mathrm{NaCl}$, $0.1 \%$ Tween 20 , and $5 \%(\mathrm{w} / \mathrm{v})$ non-fat dry milk, blots were incubated overnight at $4^{\circ} \mathrm{C}$ with the primary antibody and washed with a Tris buffer (Tris-buffered saline, $\mathrm{pH} 7.5$, containing $0.1 \%$ Tween 20 ). The blots were then incubated with horseradish peroxidase-conjugated secondary antibody (Pierce), washed again, incubated with SuperSignal Ultra Chemiluminescent reagent (Pierce), and, finally, exposed to Kodak X-Omat film (Eastman Kodak Ltd, Rochester, NY, USA).

\section{Statistical analysis}

Data are expressed as means \pm SEM unless stated otherwise. Statistical significance was assessed by the two-tailed Student's $t$ test; $p<0.05$ was considered significant.

\section{Results}

\section{Decreased expression of PPAR $\gamma \mathbf{1}$ in OA cartilage}

To examine the expression and localization of PPAR- $\gamma$ protein in cartilage, we performed an immunohistochemical analysis. We found that chondrocytes in both normal and OA cartilage express PPAR $\gamma$ protein. The immunostaining for PPAR $\gamma$ was essentially located in the superficial zones, and was lower in OA cartilage than in normal cartilage. Statistical evaluation of the cell score for PPAR $\gamma$ indicated significant differences between normal cartilage $(22 \pm 2.5 \%$ (mean \pm SEM)) and cartilage from mild to moderate OA ( $11 \pm 3 \%$; Figure 1a,b). Similarly, PPAR $\gamma$ expression was significantly reduced in severe OA cartilage (10 $\pm 2 \%$, data not shown). By contrast, in intact OA cartilage, the positive staining seemed lower, but the differences were not significant (data not shown). The specificity of the staining was confirmed by using antibodies that had been preadsorbed ( 1 hour, $37^{\circ} \mathrm{C}$ ) with a 20 -fold molar excess of the protein fragment corresponding to amino acids 6 to 105 of human PPAR (Figure 1c) or non-immune serum (Figure 1c). PPAR $\alpha$ and PPAR $\beta$ were also expressed in normal, mild to moderate, and severe OA cartilage, but no significant differences were observed between the cartilage groups (Additional file 1).

PPAR $\gamma$ has two isoforms, PPAR $\gamma 1$ and PPAR $\gamma 2$, which are generated by alternative promoters and differential splicing [9]. To examine which PPAR $\gamma$ transcripts were expressed in cartilage, we determined absolute mRNA concentrations of PPAR $\gamma 1$ and PPAR $\gamma 2$ by quantitative real-time PCR. As shown in Figure 2, PPAR $\gamma 1$ abundance represents about $90 \%$ of the total PPAR $\gamma$ mRNA. Thus, human cartilage expresses high levels of $\gamma 1 \mathrm{mRNA}$, the isoform that is generally expressed in various tissues, and low levels of the $\gamma 2$ isoform, which is more selectively expressed in adipose tissue [10]. The level of PPAR 1 expression in OA cartilage was 2.4-fold lower than in normal cartilage $(p<0.005)$. However, no significant differences in mRNA levels of PPAR $\gamma 2$ were seen between normal and $\mathrm{OA}$ cartilage (Figure 2). These observations demonstrate a selective downregulation of PPAR $\gamma 1$ in OA cartilage. In preliminary experiments we showed that the amplification efficiency of PPAR $\gamma 1$, PPAR $\gamma 2$, and GAPDH were approximately equal, ranging between 1.95 and 2 .

\section{Time-course and dose-dependent effect of IL-1 on PPAR 1 expression in chondrocytes}

The reduced expression of PPAR 1 in OA cartilage suggests that humoral factors produced in the OA joint downregulate PPAR $\gamma 1$ expression. We therefore evaluated the effect of IL-1, one of the most prominent mediators in OA, on PPAR $\gamma 1$ expression in cultured chondrocytes. OA chondrocytes were treated with $100 \mathrm{pg} / \mathrm{ml} \mathrm{IL}-1$ for $0,3,6,12$, and 24 hours; the levels of PPAR $\gamma 1$ protein were then analyzed by Western blotting. In preliminary experiments we found that, as in cartilage, cultured chondrocytes express predominantly the PPAR 1 isoform but not the adipocyte-specific PPAR 2 isoform. As shown in Figure 3a, PPAR 1 protein expression was not significantly affected after 3 hours of stimulation with IL-1. The level of PPAR $\gamma 1$ protein then started to decline gradually at 6 hours and remained low until at least 24 hours. Subsequently, we examined the effect of various concentrations of IL-1 on PPAR 1 protein expression. As shown in Figure $3 b$, the expression of PPAR $\gamma 1$ was downregulated by IL-1 in a concentration-dependent manner; significant decreases were observed at a concentration as low as $10 \mathrm{pg} / \mathrm{ml}$. Maximal decreases were obtained at an IL-1 concentration of $100 \mathrm{pg} /$ $\mathrm{ml}$ (Figure $3 \mathrm{~b}$ ). No modulation of PPAR $\alpha$ and PPAR $\beta$ expression was seen (Additional file 2).

In addition to IL-1, the pro-inflammatory mediators TNF- $\alpha$, IL17 , and $\mathrm{PGE}_{2}$ also contribute to the pathogenesis of OA [1-3]. We therefore examined their effects on PPAR $\gamma 1$ protein 
(a)

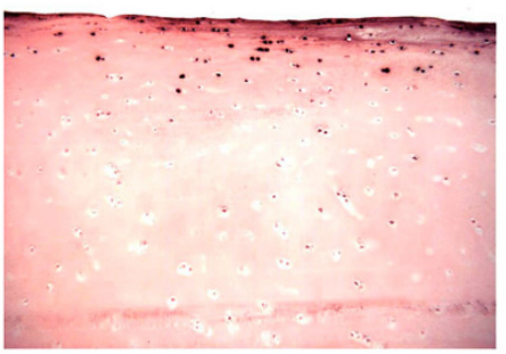

(c)

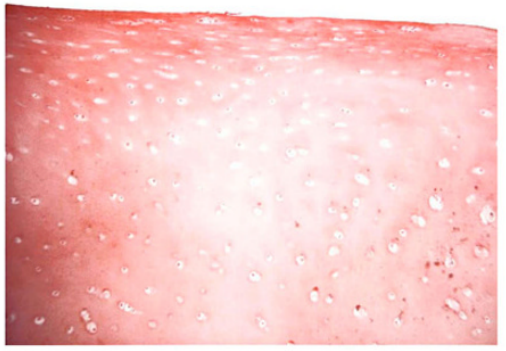

(b)

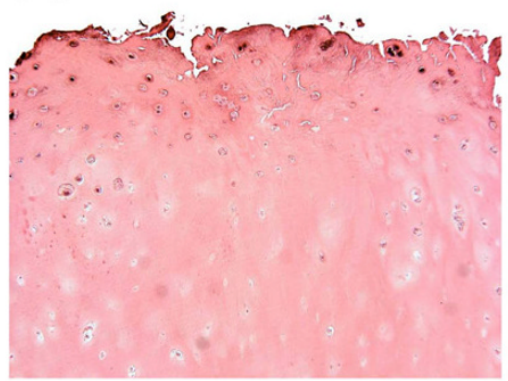

(d)

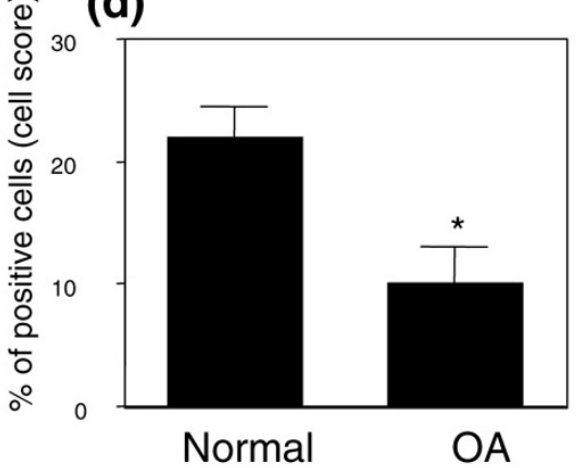

Expression of PPAR $\gamma$ protein in normal and osteoarthritis cartilage. Representative immunostaining of human normal cartilage (a) and cartilage from mild to moderate osteoarthritis (OA) (b) for peroxisome proliferator-activated receptor $\gamma$ (PPAR $\gamma$ ). (c) Normal specimens treated with anti-PPAR $\gamma$ antibody that was preadsorbed with a 20-fold molar excess of the protein fragment corresponding to amino acids 8 to 106 of human PPAR (control for staining specificity). (d) Percentage of chondrocytes expressing PPAR $\gamma$ in normal and OA cartilage. The results are means \pm SEM for 10 normal and $11 \mathrm{OA}$ specimens. ${ }^{*} p<0.05$ compared with normal cartilage.

expression. Cultured $\mathrm{OA}$ chondrocytes were incubated for 24 hours with IL-1 (100 pg/ml), TNF- $\alpha$ (1 and $10 \mathrm{ng} / \mathrm{ml})$, IL-17 $(10$ and $100 \mathrm{ng} / \mathrm{ml})$, and $\mathrm{PGE}_{2}(0.1$ and $1 \mu \mathrm{M})$, and the expression levels of PPAR $\gamma 1$ were determined by Western blotting. As shown in Figure 4, and like IL-1, TNF- $\alpha$, IL-17, and PGE also downregulated PPAR $\gamma 1$ protein expression. Similar results were obtained with normal chondrocytes $(n=3$; data not shown).

\section{Downregulation by IL-1 of PPAR $\gamma 1$ expression at the transcriptional level}

To elucidate the mechanism responsible for the changes in amounts of PPAR $\gamma 1$ protein, we measured the steady-state level of PPAR $\gamma 1$ mRNA by quantitative real-time PCR. Expression of the gene encoding GAPDH was used for normalization. The relative expression level of PPAR 1 mRNA was plotted as a percentage decrease compared with untreated control cells (Figure 5a). Consistent with its effects on protein expression (Figure 3b), IL-1 downregulates PPAR $\gamma 1$ mRNA expression in a dose-dependent manner in OA chondrocytes. The effect of IL-1 on PPAR 1 mRNA expression was maximal (about $85 \%$ decrease) at $100 \mathrm{pg} / \mathrm{ml}$. A dose-dependent effect of IL-1 on PPAR 1 mRNA expression was also observed in normal chondrocytes ( $n=3$; data not shown).

To characterize the effect of IL-1 on PPAR $\gamma 1$ expression further, we performed transient transfection experiments with the reporter construct pGL3-PPAR $\gamma 1 \mathrm{p} 3000$, containing about 3,000 base pairs of regulatory sequence of the gene encoding human PPAR 1 [9]. As shown in Figure 5b, IL-1 suppressed PPAR $\gamma 1$ promoter activity in a dose-dependent manner. The effect of IL-1 on PPAR $\gamma 1$ promoter activity was optimal at 100 $\mathrm{pg} / \mathrm{ml}$ (about 65\% decrease). Taken together, these data strongly suggest that IL-1 suppressed PPAR $\gamma 1$ expression at the transcriptional level.

The MAPKs JNK and p38, but not ERK, are involved in IL1-induced downregulation of PPAR $\gamma \mathbf{1}$

$\mathrm{IL}-1$ is known to induce its effects in chondrocytes through activation of a plethora of signaling pathways, including the mitogen-activated protein kinases (MAPKs) c-Jun N-terminal kinase (JNK), p38, and extracellular signal-regulated kinase (ERK) [20]. To assess the contribution of these pathways in the IL-1-mediated downregulation of PPAR 1 , OA 
Figure 2

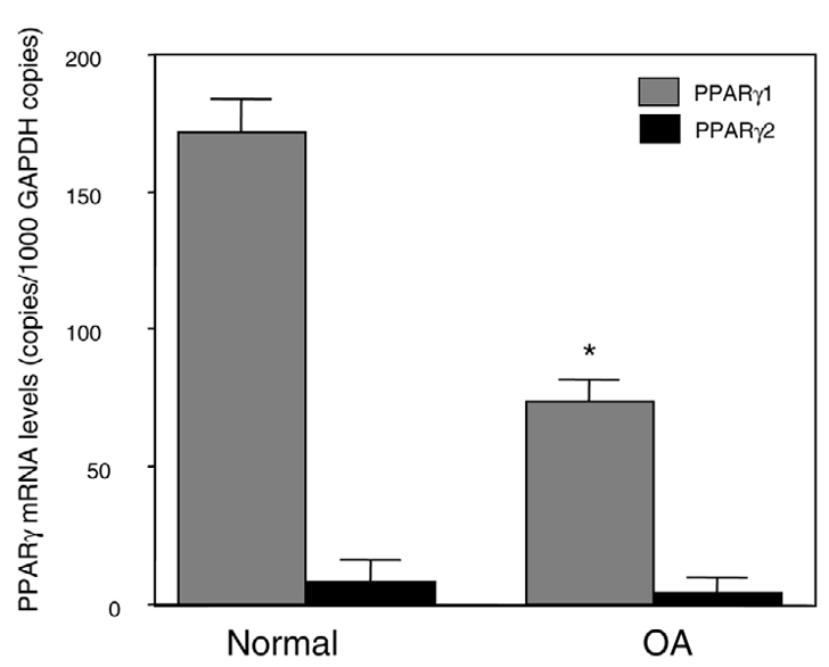

PPAR $\gamma 1$ and PPAR $\gamma 2$ mRNA levels in normal and osteoarthritis human cartilage. RNA was extracted from normal $(n=7)$ and osteoarthritis $(n$ $=8$ ) cartilage, reverse transcribed into $\mathrm{CDNA}$, and processed for realtime PCR. The threshold cycle values were converted to the number of molecules, as described in the Materials and methods section. Data were expressed as copies of the gene's mRNA detected per 1,000 glyceraldehyde-3-phosphate dehydrogenase copies. ${ }^{*} p<0.05 \mathrm{com}$ pared with normal samples. PPAR, peroxisome proliferator-activated receptor.

chondrocytes were pretreated for 30 minutes with selective inhibitors for the above pathways, and then stimulated or not with IL-1 for 18 hours. Total cell lysates were analyzed for PPAR $\gamma 1$ protein expression by Western blotting. As shown in Figure 6a, IL-1 reduced PPAR 1 expression remarkably, confirming the results seen previously (Figure 3). Pretreatment with SB203580, a specific p38 MAPK inhibitor, as well as pretreatment with SP600125, a selective inhibitor of JNK, dose-dependently abolished IL-1-induced downregulation of PPAR 1 expression. Conversely, PD98059, a selective inhibitor of ERK, had no effect on IL-1-induced downregulation of PPAR $\gamma$ expression, even at a high concentration $(20 \mu \mathrm{M})$. None of the MAPK inhibitors had an effect on PPAR $\gamma$ expression in the absence of IL-1. These results suggest that the MAPKs JNK and p38, but not ERK, are involved in the suppression of PPAR $\gamma 1$ expression by IL-1.

\section{Mediation of IL-1-induced downregulation of PPAR $\gamma 1$ by NF-KB}

Because NF- $\kappa B$ mediates many of the effects of IL-1 in a variety of cell types including chondrocytes, we examined the role of this transcription factor in the repression of PPAR $\gamma 1$. We used three different pharmacological inhibitors of the NF- $\kappa B$ pathway: the antioxidant PDTC, a proteasome inhibitor MG132 , and an inhibitor of NF- $\mathrm{KB}$ translocation (SN-50). Cells were pretreated with increasing concentrations of each inhibitor for 30 minutes and then subsequently treated with $100 \mathrm{pg}$ of IL-1 for 18 hours.
Figure 3

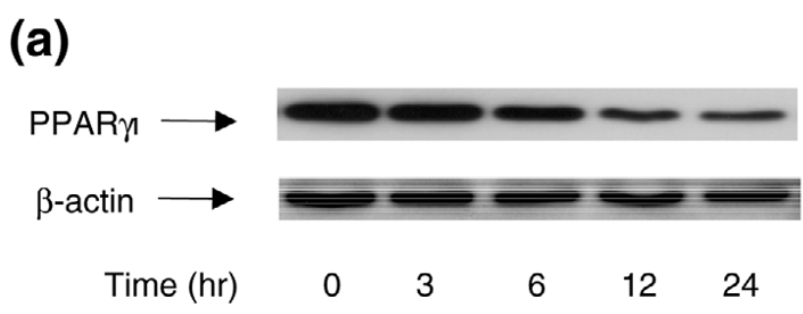

(b)

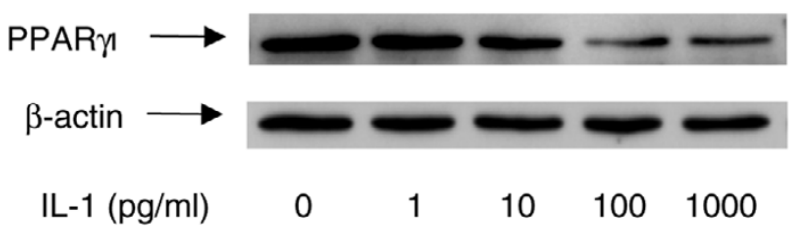

Effect of IL-1 on PPAR $\gamma 1$ protein expression in osteoarthritis chondrocytes. (a) Osteoarthritis (OA) chondrocytes were treated with $100 \mathrm{pg} /$ $\mathrm{ml} \mathrm{IL-1}$ for the indicated periods. (b) OA chondrocytes were treated with increasing concentrations of IL-1 for 24 hours. Cell lysates were prepared and analyzed for peroxisome proliferator-activated receptor $\gamma 1$ (PPAR $\gamma 1$ ) protein by Western blotting (upper panels). The blots were stripped and reprobed with a specific anti- $\beta$-actin antibody (lower panels). The blots are representative of similar results obtained from four independent experiments.

As shown in Figure 6b, treatment with IL-1 decreased PPAR $\gamma 1$ expression, but this IL-1 effect was dose-dependently abolished in the presence of each of the three NF- $\kappa B$ inhibitors (PDTC, MG-132, and SN-50). None of the NF- $\kappa B$ inhibitors had an effect on basal PPAR 1 expression. These results imply that NF- $\kappa B$ activation participates in the IL-1-mediated downregulation of PPAR $\gamma 1$ expression.

\section{Discussion}

There is considerable evidence for the importance of PPAR $\gamma$ in OA because of its potential beneficial effects. It is expressed by all major cells in joints, including chondrocytes $[11,13]$. Natural and synthetic ligands of PPAR $\gamma$ were shown to inhibit the expression of several inflammatory and catabolic genes in cultured chondrocytes $[4,11,12]$ and to exhibit anti-inflammatory and chondroprotective effects in an experimental animal model of OA [18]. However, little is known about the expression and regulation of PPAR $\gamma$ expression in cartilage. Here, we analyzed the expression of PPAR $\gamma$ in OA and normal cartilage, and studied the effect of IL-1, a prominent cytokine in OA, on PPAR $\gamma$ expression in cultured chondrocytes.

This is the first study to demonstrate that human cartilage expresses predominantly PPAR $\gamma 1 \mathrm{mRNA}$ and that the levels of PPAR 1 are decreased in OA in comparison with normal cartilage. Our immunohistochemistry analysis showed that PPAR $\gamma$ was located essentially in the superficial zone of carti- 

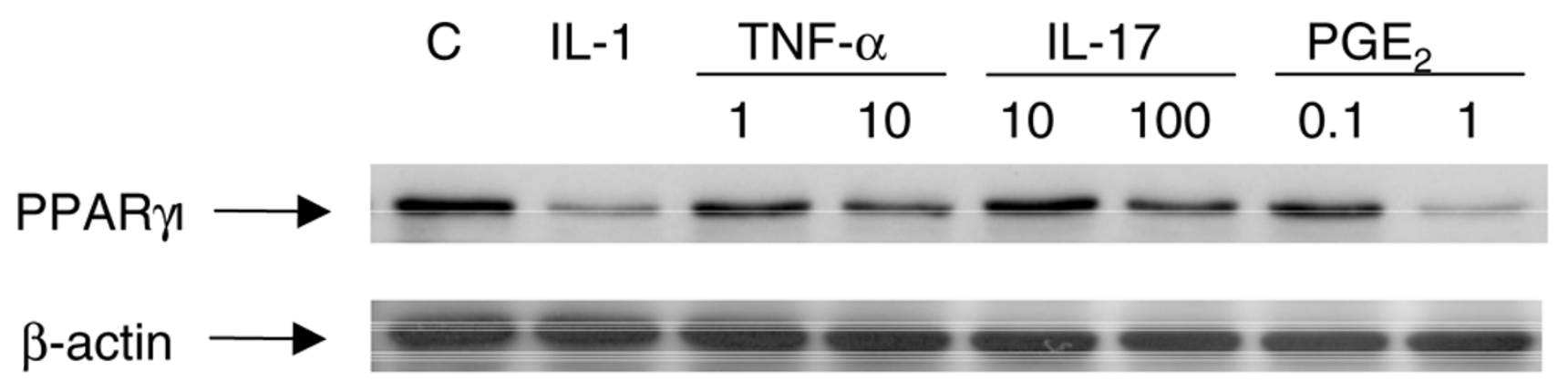

Effect of TNF- $\alpha, \mathrm{IL}-17$ and prostaglandin $\mathrm{E}_{2}$ on PPAR $\gamma 1$ protein expression in osteoarthritis chondrocytes. Cells were treated with IL-1 (100 pg/ml), TNF- $\alpha(1$ and $10 \mathrm{ng} / \mathrm{ml}), \mathrm{LL}-17(10$ and $100 \mathrm{ng} / \mathrm{ml})$, and prostaglandin $\mathrm{E}_{2}(0.1$ and $1 \mu \mathrm{M})$. After 24 hours, cell lysates were prepared and analyzed for peroxisome proliferator-activated receptor $\gamma 1$ (PPAR $\gamma 1$ ) protein expression by Western blotting. In the lower panel, the blots were stripped and reprobed with a specific anti- $\beta$-actin antibody. The blots are representative of similar results obtained from four independent experiments.

lage and that the levels of PPAR $\gamma$ expression in OA cartilage were lower than in normal cartilage.

Altered expression of PPAR $\gamma$ was observed in several other inflammatory disorders. For instance, PPAR $\gamma$ expression was shown to be reduced in atherosclerotic tissues [21], in epithelial cells from patients with ulcerative colitis [22], in peripheral blood mononuclear cells from patients with multiple sclerosis [23], in alveolar macrophages from patients with allergic asthma [24], and in nasal polyposis from patients with allergic rhinitis [25]. In contrast, PPAR $\gamma$ expression was shown to be elevated in brains of patients with Alzheimer's disease [26], in bronchial epithelium and airway smooth muscle cells of asthmatic patients [27], and in T cells isolated from patients with sepsis [28]. Taken together, these results suggest that tissuespecific regulation of PPAR $\gamma$ expression is extremely complex.

To determine which factors might downregulate PPAR $\gamma$ expression in cartilage, we tested the impact of IL-1, which accumulates in chondrocytes in the superficial zone of OA cartilage $[29,30]$ and has a pivotal role in the initiation and progression of OA [1-3]. Our results revealed that exposure to IL1 downregulates PPAR $\gamma$ protein expression in chondrocytes in a time- and dose-dependent manner. It should be noted that TNF- $\alpha, I L-17$, and $P G E_{2}$, which are known to contribute to the pathogenesis of OA, also downregulate PPAR $\gamma$ gene expression. We therefore cannot exclude the possibility of a role for these inflammatory mediators in PPAR $\gamma$ downregulation in cartilage in vivo. Given the anti-inflammatory and anti-catabolic functions of PPAR $\gamma$, it is reasonable to speculate that the suppression of PPAR $\gamma$ expression by inflammatory mediators in chondrocytes presents a new and additional mechanism by which these mediators contribute to the pathogenesis of OA. Our findings are consistent with other studies showing that pro-inflammatory stimuli downregulate PPAR $\gamma$ expression in chondrocytes [31-33] and synovial fibroblasts [34,35]. In contrast, Shan and colleagues [36] found that IL-1 upregulates
PPAR $\gamma$ expression in chondrocytes. The reasons for these discrepancies are not clear and could be due to small differences in chondrocyte preparation, culture conditions, and/or detection methods.

Suppression of PPAR $\gamma 1$ expression by IL-1 in chondrocytes probably occurs at the transcriptional level, because reporter gene assays revealed a decrease in PPAR $\gamma 1$ promoter activity by IL-1. As an alternative to an effect on PPAR $\gamma 1$ promoter, we could not exclude a specific effect of IL-1 on the stability of PPAR $\gamma 1$ mRNA.

The MAPKs JNK, p38, and ERK are activated by IL-1 and mediate many of the effects of IL-1 in chondrocytes [20]. To determine whether these MAPKs are involved in the IL-1-mediated downregulation of PPAR $\gamma 1$ expression, we employed specific inhibitors of the three MAPKs. We found that SB203580 and SP600125 - specific inhibitors of the MAPKs p38 and JNK, respectively - almost completely abolished the IL-1-mediated downregulation of PPAR $\gamma 1$ expression, whereas PD98059 - an inhibitor of the MAPK ERK- was without effect. These data suggest that the MAPKs JNK and p38, but not ERK, mediate IL-1-induced downregulation of PPAR $\gamma 1$ expression in chondrocytes. The NF- $\kappa B$ pathway also mediates many effects of IL-1 in chondrocytes [37-41]. We demonstrate here that three compounds that interfere with NF$\kappa \mathrm{B}$ activation, the anti-oxidant PDTC, the proteasome inhibitor $\mathrm{MG}-132$, and an inhibitor of NF- $\mathrm{BB}$ translocation SN-50, blocked the suppressive effect of IL-1, suggesting the involvement of NF-KB in the IL-1-mediated downregulation of PPAR $\gamma 1$ in chondrocytes. Thus, IL-1 engages both the MAPK (JNK and p38) and the NF-KB pathways to suppress PPAR $\gamma 1$ expression, although it is not clear whether these pathways act on the same axis or in parallel. Downstream nuclear events in JNK, p38, and NF-KB signaling pathways leading to the regulation of gene expression in chondrocytes include the activation of the transcription factors $\mathrm{AP}-1$ and $\mathrm{NF}-\kappa \mathrm{B}$ 
Figure 5

(a)

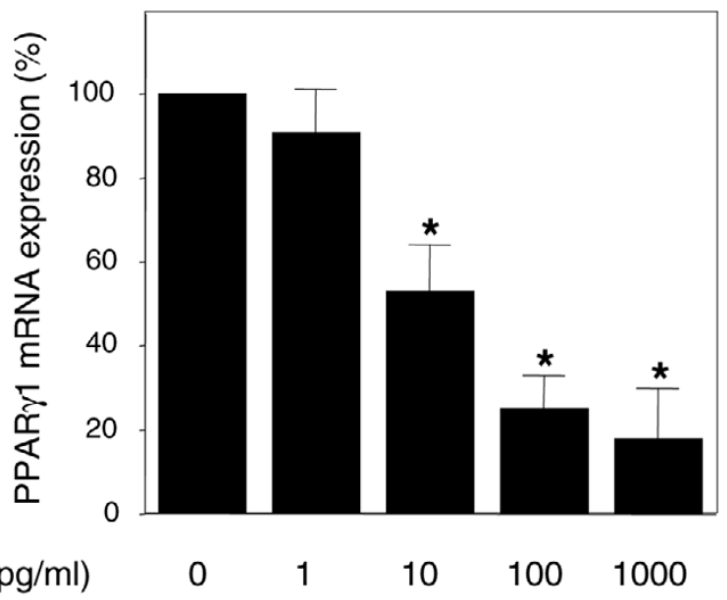

(b)

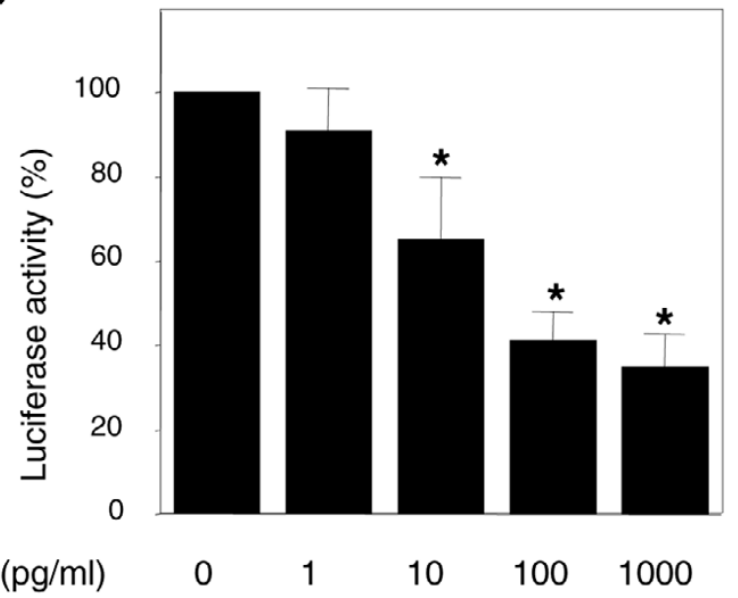

IL-1 downregulates PPAR 1 expression at the transcriptional level. (a) Osteoarthritis $(\mathrm{OA})$ chondrocytes were treated with increasing concentrations of IL-1 for 12 hours. Total RNA was isolated and reverse transcribed into $\mathrm{cDNA}$, and peroxisome proliferator-activated receptor $\gamma 1$ (PPAR 1 1) and glyceraldehyde-3-phosphate dehydrogenase mRNAs were quantified by real-time PCR. All experiments were performed in triplicate, and negative controls without template RNA were included in each experiment. (b) OA chondrocytes were co-transfected with $1 \mu \mathrm{g}$ per well of the PPAR $\gamma 1$ promoter (pGL3-PPAR $\gamma 1$ p3000) and $0.5 \mu \mathrm{g}$ per well of the internal control pSV40- $\beta$-galactosidase, using FuGene 6 transfection reagent. The next day, transfected cells were treated with increasing concentrations of IL-1 for 18 hours. Luciferase activity values were determined and normalized to $\beta$-galactosidase activity. Results are expressed as percentage changes, taking the value of untreated cells as $100 \%$, and show means \pm SEM for four independent experiments. ${ }^{*} p<0.05$ compared with untreated cells.

$[20,37,38,40-43]$. The human PPAR 1 promoter contains binding sites for both AP-1 and NF- $\kappa B$ [9]. It is therefore possible that AP-1 and NF-KB mediate IL-1-induced downregula-
Figure 6

(a)

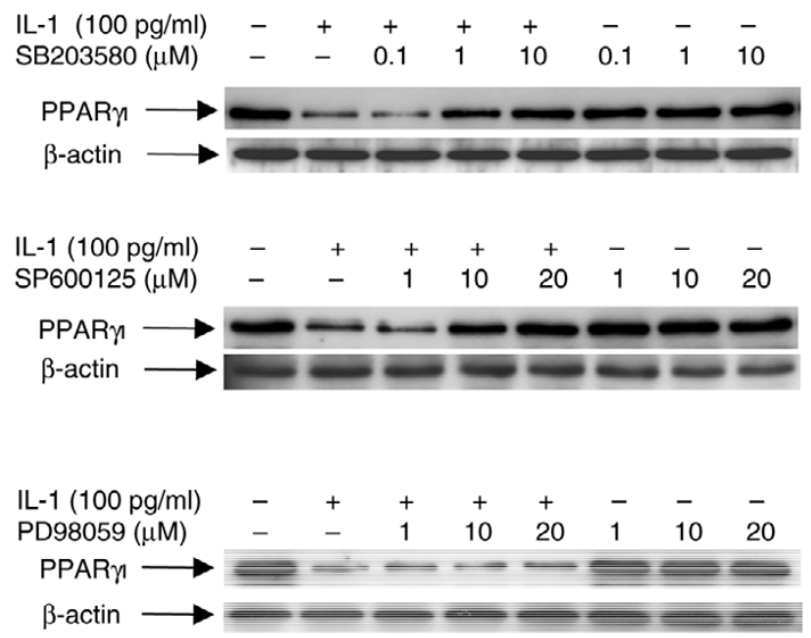

(b)

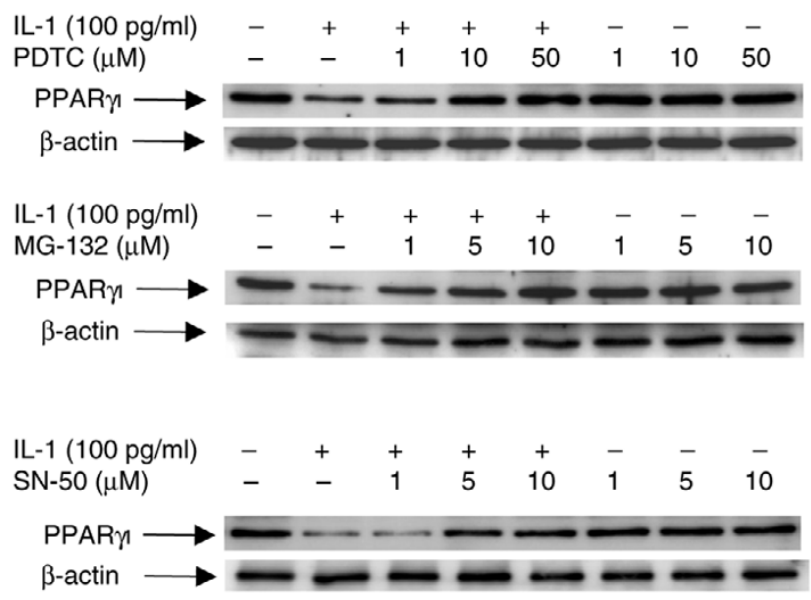

Effect of mitogen-activated protein kinase and NF-KB inhibitors on IL-1induced downregulation of PPAR 1 expression. (a) Osteoarthritis (OA) chondrocytes were exposed to increasing concentrations of SB203580 (p38 mitogen-activated protein kinase inhibitor),

SP600125 (c-Jun N-terminal kinase inhibitor) and PD98059 (extracellular signal-regulated kinase inhibitor) for 30 minutes before treatment with or without IL-1 (100 pg/ml). (b) OA chondrocytes were exposed to increasing concentrations of various inhibitors of NF-KB (pyrrolidine dithiocarbamate, MG-132, and SN-50) for 30 minutes before stimulation with or without IL-1 $(100 \mathrm{pg} / \mathrm{ml})$. After 24 hours, cell lysates were prepared and analyzed for peroxisome proliferator-activated receptor $\gamma 1$ (PPAR $\gamma 1$ ) protein expression by Western blotting. In the lower panels, the blots were stripped and reprobed with a specific anti- $\beta$-actin antibody. The blots are representative of similar results obtained from four independent experiments.

tion of PPAR $\gamma 1$ expression. Although they are historically characterized as transcriptional activators, several reports have recently defined $\mathrm{AP}-1$ and $\mathrm{NF}-\mathrm{KB}$ as transcriptional 
repressors [44-50]. Analysis of PPAR 1 promoter in a promoter reporter construct, with mutation of the AP-1 and NF- $\kappa B$ response elements and the use of small interfering RNA technology, will contribute to our understanding of the importance of $\mathrm{AP}-1$ and NF- $\mathrm{KB}$ in the IL-1-induced downregulation of PPAR $\gamma 1$ expression.

The physiological significance of reduced expression of PPAR $\gamma$ in OA cartilage is of considerable interest, given the protective functions of PPAR $\gamma$ in cartilage. Indeed, we and others have previously reported that PPAR $\gamma$ activators inhibit several inflammatory and catabolic events involved in the pathogenesis of OA $[4,11,12,32-34]$. PPAR $\gamma$ activation was also shown to prevent the proteoglycan degradation induced by pro-inflammatory cytokines [13]. Furthermore, PPAR $\gamma$ ligands were shown to reduce the incidence and severity of $\mathrm{OA}$ in an experimental model, preventing inflammatory and catabolic responses as well as cartilage degradation [18]. All these data suggest that PPAR $\gamma$ has a protective role in OA. This is strengthened by the observation that PPAR $\gamma$ haploinsufficiency exacerbates experimentally induced arthritis [51]. It is therefore tempting to speculate that diminished expression of PPAR $\gamma$ in OA cartilage may, at least in part, be involved in increased expression of inflammatory and catabolic genes, promoting articular inflammation and cartilage degradation. In addition, the observation that IL-1 and other pro-inflammatory mediators downregulate PPAR $\gamma 1$ expression in chondrocytes has important implications for our understanding of the pathophysiology of OA.

\section{Conclusion}

The decreased expression of PPAR $\gamma$ in OA cartilage and the literature supporting a protective role for PPAR $\gamma$ in OA raise the possibility that upregulation of PPAR $\gamma$ may be beneficial in the context of preventing and treating $\mathrm{OA}$. Additional studies to define the molecular mechanisms controlling the expression of PPAR $\gamma$ are therefore urgently needed. Such research will no doubt add to our understanding of the pathogenesis of OA, and could lead to the development of new therapeutic strategies in the prevention and treatment of $\mathrm{OA}$ and possibly other arthritic diseases.

\section{Competing interests}

The authors declare that they have no competing interests.

\section{Authors' contributions}

HA conceived the study, designed and performed cell and real-time RT-PCR experiments and some immunohistochemistry experiments. MB participated in the study design and data analysis. LM-E performed some immunohistochemistry experiments. JM-P, J-PP, and ND helped to obtain tissues, participated in some immunohistochemistry studies and gave critical comments on the manuscripts. HF conceived, designed, and coordinated the study, performed some cell experiments, and drafted the manuscript. All authors read and approved the final manuscript.

\section{Additional files}

The following Additional files are available online:

\section{Additional file 1}

A PDF file showing the expression of PPAR $\alpha$ and PPAR $\beta$ proteins in normal and OA cartilage.

See http://www.biomedcentral.com/content/ supplementary/ar2151-S1.pdf

\section{Additional file 2}

A PowerPoint file showing the effect of IL- 1 on PPAR $\alpha$ and PPAR $\beta$ protein expression in OA chondrocytes.

See http://www.biomedcentral.com/content/ supplementary/ar2151-S2.ppt

\section{Acknowledgements}

The authors thank J Auwerx for the PPARg1 promoter, and M Boily for help and critical comments. This work was supported by the Canadian Institutes of Health Research (CIHR) Grant IMH-63168, and the Fonds de la Recherche du Centre de Recherche du Centre Hospitalier de I'Université de Montréal (CHUM). HF is a Research Scholar of the Fonds de Recherche en Santé du Québec (FRSQ).

\section{References}

1. Goldring MB: The role of cytokines as inflammatory mediators in osteoarthritis: lessons from animal models. Connect Tissue Res 1999, 40:1-11.

2. Pelletier JP, Martel-Pelletier J, Abramson SB: Osteoarthritis, an inflammatory disease: potential implication for the selection of new therapeutic targets. Arthritis Rheum 2001, 44:1237-1247.

3. Goldring MB, Berenbaum F: The regulation of chondrocyte function by proinflammatory mediators: prostaglandins and nitric oxide. Clin Orthop Relat Res 2004:S37-S46.

4. Li X, Afif H, Cheng S, Martel-Pelletier J, Pelletier JP, Ranger P Fahmi $\mathrm{H}$ : Expression and regulation of microsomal prostaglandin $E$ synthase-1 in human osteoarthritic cartilage and chondrocytes. J Rheumatol 2005, 32:887-895.

5. Fahmi H, Pelletier JP, Martel-Pelletier J: PPAR $\gamma$ ligands as modulators of inflammatory and catabolic responses on arthritis. An overview. J Rheumatol 2002, 29:3-14.

6. Braissant O, Foufelle F, Scotto C, Dauca M, Wahli W: Differential expression of peroxisome proliferator-activated receptors (PPARs): tissue distribution of PPAR- $\alpha,-\beta$, and $-\gamma$ in the adult rat. Endocrinology 1996, 137:354-366.

7. Barish GD, Narkar VA, Evans RM: PPAR $\delta$ : a dagger in the heart of the metabolic syndrome. J Clin Invest 2006, 116:590-597.

8. Zhu Y, Qi C, Korenberg JR, Chen XN, Noya D, Rao MS, Reddy JK: Structural organization of mouse peroxisome proliferatoractivated receptor $\gamma$ (mPPAR $\gamma$ ) gene: alternative promoter use and different splicing yield two mPPAR $\gamma$ isoforms. Proc Natl Acad Sci USA 1995, 92:7921-7925.

9. Fajas L, Auboeuf D, Raspe E, Schoonjans K, Lefebvre AM, Saladin R, Najib J, Laville M, Fruchart JC, Deeb S, et al.: The organization, promoter analysis, and expression of the human PPAR $\gamma$ gene. $J$ Biol Chem 1997, 272:18779-18789.

10. Vidal-Puig A, Jimenez-Linan M, Lowell BB, Hamann A, Hu E Spiegelman B, Flier JS, Moller DE: Regulation of PPAR $\gamma$ gene expression by nutrition and obesity in rodents. J Clin Invest 1996, 97:2553-2561. 
11. Fahmi H, Di Battista JA, Pelletier JP, Mineau F, Ranger $P$, MartelPelletier J: Peroxisome proliferator-activated receptor $\gamma$ activators inhibit interleukin-1 $\beta$-induced nitric oxide and matrix metalloproteinase 13 production in human chondrocytes. Arthritis Rheum 2001, 44:595-607.

12. Fahmi H, Pelletier JP, Mineau F, Martel-Pelletier J: $15 \mathrm{~d}-\mathrm{PGJ}_{2}$ is acting as a 'dual agent' on the regulation of COX-2 expression in human osteoarthritic chondrocytes. Osteoarthritis Cartilage 2002, 10:845-848.

13. Bordji K, Grillasca JP, Gouze JN, Magdalou J, Schohn H, Keller JM, Bianchi A, Dauca M, Netter P, Terlain B: Evidence for the presence of peroxisome proliferator-activated receptor (PPAR) $\alpha$ and $\gamma$ and retinoid $Z$ receptor in cartilage. PPAR $\gamma$ activation modulates the effects of interleukin-1 $\beta$ on rat chondrocytes. J Biol Chem 2000, 275:12243-12250.

14. Ji JD, Cheon H, Jun JB, Choi SJ, Kim YR, Lee YH, Kim TH, Chae IJ, Song GG, Yoo DH, et al:: Effects of peroxisome proliferatoractivated receptor- $\gamma$ (PPAR- $\gamma$ ) on the expression of inflammatory cytokines and apoptosis induction in rheumatoid synovial fibroblasts and monocytes. J Autoimmun 2001, 17:215-221.

15. Fahmi H, Pelletier JP, Di Battista JA, Cheung HS, Fernandes J, Martel-Pelletier J: Peroxisome proliferator-activated receptor $\gamma$ activators inhibit MMP-1 production in human synovial fibroblasts by reducing the activity of the activator protein 1. Osteoarthritis Cartilage 2002, 10:100-108.

16. Cheng S, Afif H, Martel-Pelletier J, Pelletier JP, Li X, Farrajota K, Lavigne $\mathrm{M}$, Fahmi $\mathrm{H}$ : Activation of peroxisome proliferator-activated receptor $\gamma$ inhibits interleukin-1 $\beta$-induced membraneassociated prostaglandin E2 synthase-1 expression in human synovial fibroblasts by interfering with Egr-1. J Biol Chem 2004, 279:22057-22065.

17. Jiang C, Ting AT, Seed B: PPAR- $\gamma$ agonists inhibit production of monocyte inflammatory cytokines. Nature 1998, 391:82-86.

18. Kobayashi T, Notoya K, Naito T, Unno S, Nakamura A, Martel-Pelletier J, Pelletier JP: Pioglitazone, a peroxisome proliferatoractivated receptor $\gamma$ agonist, reduces the progression of experimental osteoarthritis in guinea pigs. Arthritis Rheum 2005, 52:479-487.

19. Altman R, Asch E, Bloch D, Bole G, Borenstein D, Brandt K, Christy W, Cooke TD, Greenwald R, Hochberg M, et al:: Development of criteria for the classification and reporting of osteoarthritis. Classification of osteoarthritis of the knee. Diagnostic and Therapeutic Criteria Committee of the American Rheumatism Association. Arthritis Rheum 1986, 29:1039-1049.

20. Geng Y, Valbracht J, Lotz M: Selective activation of the mitogenactivated protein kinase subgroups c-Jun NH2 terminal kinase and p38 by IL-1 and TNF in human articular chondrocytes. J Clin Invest 1996, 98:2425-2430.

21. Soumian S, Gibbs R, Davies A, Albrecht C: mRNA expression of genes involved in lipid efflux and matrix degradation in occlusive and ectatic atherosclerotic disease. J Clin Pathol 2005, 58:1255-1260.

22. Dubuquoy L, Jansson EA, Deeb S, Rakotobe S, Karoui M, Colombel JF, Auwerx J, Pettersson S, Desreumaux P: Impaired expression of peroxisome proliferator-activated receptor gamma in ulcerative colitis. Gastroenterology 2003, 124:1265-1276.

23. Klotz L, Schmidt M, Giese T, Sastre M, Knolle P, Klockgether T, Heneka MT: Proinflammatory stimulation and pioglitazone treatment regulate peroxisome proliferator-activated receptor $\gamma$ levels in peripheral blood mononuclear cells from healthy controls and multiple sclerosis patients. J Immunol 2005, 175:4948-4955

24. Kobayashi M, Thomassen MJ, Rambasek T, Bonfield TL, Raychaudhuri B, Malur A, Winkler AR, Barna BP, Goldman SJ, Kavuru MS: An inverse relationship between peroxisome proliferatoractivated receptor $\gamma$ and allergic airway inflammation in an allergen challenge model. Ann Allergy Asthma Immunol 2005 , 95:468-473.

25. Cardell LO, Hagge M, Uddman R, Adner M: Downregulation of peroxisome proliferator-activated receptors (PPARs) in nasal polyposis. Respir Res 2005, 6:132.

26. Kitamura $Y$, Shimohama $S$, Koike $H$, Kakimura J, Matsuoka $Y$ Nomura Y, Gebicke-Haerter PJ, Taniguchi T: Increased expression of cyclooxygenases and peroxisome proliferator-activated receptor- $\gamma$ in Alzheimer's disease brains. Biochem Biophys Res Commun 1999, 254:582-586.
27. Benayoun L, Letuve S, Druilhe A, Boczkowski J, Dombret MC, Mechighel P, Megret J, Leseche G, Aubier M, Pretolani M: Regulation of peroxisome proliferator-activated receptor $\gamma$ expression in human asthmatic airways: relationship with proliferation, apoptosis, and airway remodeling. $A m \mathrm{~J}$ Respir Crit Care Med 2001, 164:1487-1494.

28. Soller M, Tautenhahn A, Brune B, Zacharowski K, John S, Link H, von Knethen A: Peroxisome proliferator-activated receptor $\gamma$ contributes to T lymphocyte apoptosis during sepsis. J Leukoc Biol 2006, 79:235-243.

29. Tetlow LC, Adlam DJ, Woolley DE: Matrix metalloproteinase and proinflammatory cytokine production by chondrocytes of human osteoarthritic cartilage: associations with degenerative changes. Arthritis Rheum 2001, 44:585-594.

30. Towle CA, Hung HH, Bonassar LJ, Treadwell BV, Mangham DC: Detection of interleukin-1 in the cartilage of patients with osteoarthritis: a possible autocrine/paracrine role in pathogenesis. Osteoarthritis Cartilage 1997, 5:293-300.

31. Boyault S, Simonin MA, Bianchi A, Compe E, Liagre B, Mainard D, Becuwe P, Dauca M, Netter P, Terlain B, Bordji K: 15-Deoxy- $\delta$ 12,14-PGJ, but not troglitazone, modulates IL-1 $\beta$ effects in human chondrocytes by inhibiting NF- $\kappa B$ and AP-1 activation pathways. FEBS Lett 2001, 501:24-30.

32. Francois $M$, Richette $P$, Tsagris $L$, Raymondjean $M$, FulchignoniLataud MC, Forest C, Savouret JF, Corvol MT: Peroxisome proliferator-activated receptor- $\gamma$ down-regulates chondrocyte matrix metalloproteinase-1 via a novel composite element. J Biol Chem 2004, 279:28411-28418.

33. Poleni PE, Bianchi A, Etienne S, Koufany M, Sebillaud S, Netter P Terlain B, Jouzeau JY: Agonists of peroxisome proliferatorsactivated receptors (PPAR) $\alpha, \beta / \delta$ or $\gamma$ reduce transforming growth factor (TGF)- $\beta$-induced proteoglycans' production in chondrocytes. Osteoarthritis Cartilage 2006 in press.

34. Simonin MA, Bordji K, Boyault S, Bianchi A, Gouze E, Becuwe P Dauca M, Netter P, Terlain B: PPAR- $\gamma$ ligands modulate effects of LPS in stimulated rat synovial fibroblasts. Am J Physiol Cell Physiol 2002, 282:C125-C133.

35. Moulin D, Bianchi A, Boyault S, Sebillaud S, Koufany M, Francois $M$, Netter $P$, Jouzeau JY, Terlain B: Rosiglitazone induces interleukin-1 receptor antagonist in interleukin-1 $\beta$-stimulated rat synovial fibroblasts via a peroxisome proliferator-activated receptor $\beta / \delta$-dependent mechanism. Arthritis Rheum 2005, 52:759-769.

36. Shan ZZ, Masuko-Hongo K, Dai SM, Nakamura H, Kato T, Nishioka $\mathrm{K}$ : A potential role of $15-$ deoxy- $\delta(12,14)$-prostaglandin $\mathrm{J}_{2}$ for induction of human articular chondrocyte apoptosis in arthritis. J Biol Chem 2004, 279:37939-37950.

37. Ding GJ, Fischer PA, Boltz RC, Schmidt JA, Colaianne JJ, Gough A, Rubin RA, Miller DK: Characterization and quantitation of NF$\kappa B$ nuclear translocation induced by interleukin-1 and tumor necrosis factor- $\alpha$. Development and use of a high capacity fluorescence cytometric system. J Biol Chem 1998, 273:28897-28905.

38. Mengshol JA, Vincenti MP, Coon Cl, Barchowsky A, Brinckerhoff $\mathrm{CE}$ : Interleukin-1 induction of collagenase 3 (matrix metalloproteinase 13) gene expression in chondrocytes requires p38, $\mathrm{c}$-Jun $\mathrm{N}$-terminal kinase, and nuclear factor $\kappa \mathrm{B}$ : differential regulation of collagenase 1 and collagenase 3. Arthritis Rheum 2000, 43:801-811.

39. Mendes AF, Caramona MM, Carvalho AP, Lopes MC: Role of mitogen-activated protein kinases and tyrosine kinases on IL1 -induced NF- $\kappa B$ activation and iNOS expression in bovine articular chondrocytes. Nitric Oxide 2002, 6:35-44.

40. Liacini A, Sylvester J, Li WQ, Huang W, Dehnade F, Ahmad M, Zafarullah $M$ : Induction of matrix metalloproteinase-13 gene expression by TNF- $\alpha$ is mediated by MAP kinases, AP-1, and NF- $\mathrm{B}$ transcription factors in articular chondrocytes. Exp Cell Res 2003, 288:208-217.

41. Fan $Z$, Bau B, Yang $H$, Aigner T: IL-1 $\beta$ induction of IL-6 and LIF in normal articular human chondrocytes involves the ERK, p38 and $N_{F} \mathrm{~B}$ signaling pathways. Cytokine 2004, 28:17-24.

42. Liacini A, Sylvester J, Li WQ, Zafarullah M: Inhibition of interleukin-1-stimulated MAP kinases, activating protein-1 (AP-1) and nuclear factor $\kappa B(N F-\kappa B)$ transcription factors down-regulates matrix metalloproteinase gene expression in articular chondrocytes. Matrix Biol 2002, 21:251-262. 
43. Miyazaki $Y$, Tsukazaki T, Hirota $Y$, Yonekura A, Osaki M, Shindo $H$, Yamashita S: Dexamethasone inhibition of TGF $\beta$-induced cell growth and type II collagen mRNA expression through ERKintegrated AP-1 activity in cultured rat articular chondrocytes. Osteoarthritis Cartilage 2000, 8:378-385.

44. Bushel P, Kim JH, Chang W, Catino JJ, Ruley HE, Kumar CC: Two serum response elements mediate transcriptional repression of human smooth muscle $\alpha$-actin promoter in ras-transformed cells. Oncogene 1995, 10:1361-1370.

45. Schreiber M, Kolbus A, Piu F, Szabowski A, Mohle-Steinlein U, Tian J, Karin M, Angel P, Wagner EF: Control of cell cycle progression by c-Jun is p53 dependent. Genes Dev 1999, 13:607-619.

46. Takakura M, Kyo S, Inoue M, Wright WE, Shay JW: Function of AP-1 in transcription of the telomerase reverse transcriptase gene (TERT) in human and mouse cells. Mol Cell Biol 2005, 25:8037-8043

47. Toliver-Kinsky T, Wood T, Perez-Polo JR: Nuclear factor $\kappa B / p 49$ is a negative regulatory factor in nerve growth factor-induced choline acetyltransferase promoter activity in PC12 cells. J Neurochem 2000, 75:2241-2251.

48. Wachtel M, Bolliger MF, Ishihara H, Frei K, Bluethmann H, Gloor SM: Down-regulation of occludin expression in astrocytes by tumour necrosis factor (TNF) is mediated via TNF type-1 receptor and nuclear factor- $\kappa B$ activation. J Neurochem 2001, 78:155-162.

49. Sohur US, Dixit MN, Chen CL, Byrom MW, Kerr LA: Rel/NF- kB represses bcl-2 transcription in pro-B lymphocytes. Gene Expr 1999, 8:219-229.

50. Todorov VT, Volkı S, Muller M, Bohla A, Klar J, Kunz-Schughart LA, Hehlgans T, Kurtz A: Tumor necrosis factor- $\alpha$ activates NFKB to inhibit renin transcription by targeting cAMP-responsive element. J Biol Chem 2004, 279:1458-1467.

51. Setoguchi K, Misaki Y, Terauchi Y, Yamauchi T, Kawahata K, Kadowaki T, Yamamoto K: Peroxisome proliferator-activated receptor- $\gamma$ haploinsufficiency enhances B cell proliferative responses and exacerbates experimentally induced arthritis. $J$ Clin Invest 2001, 108:1667-1675. 